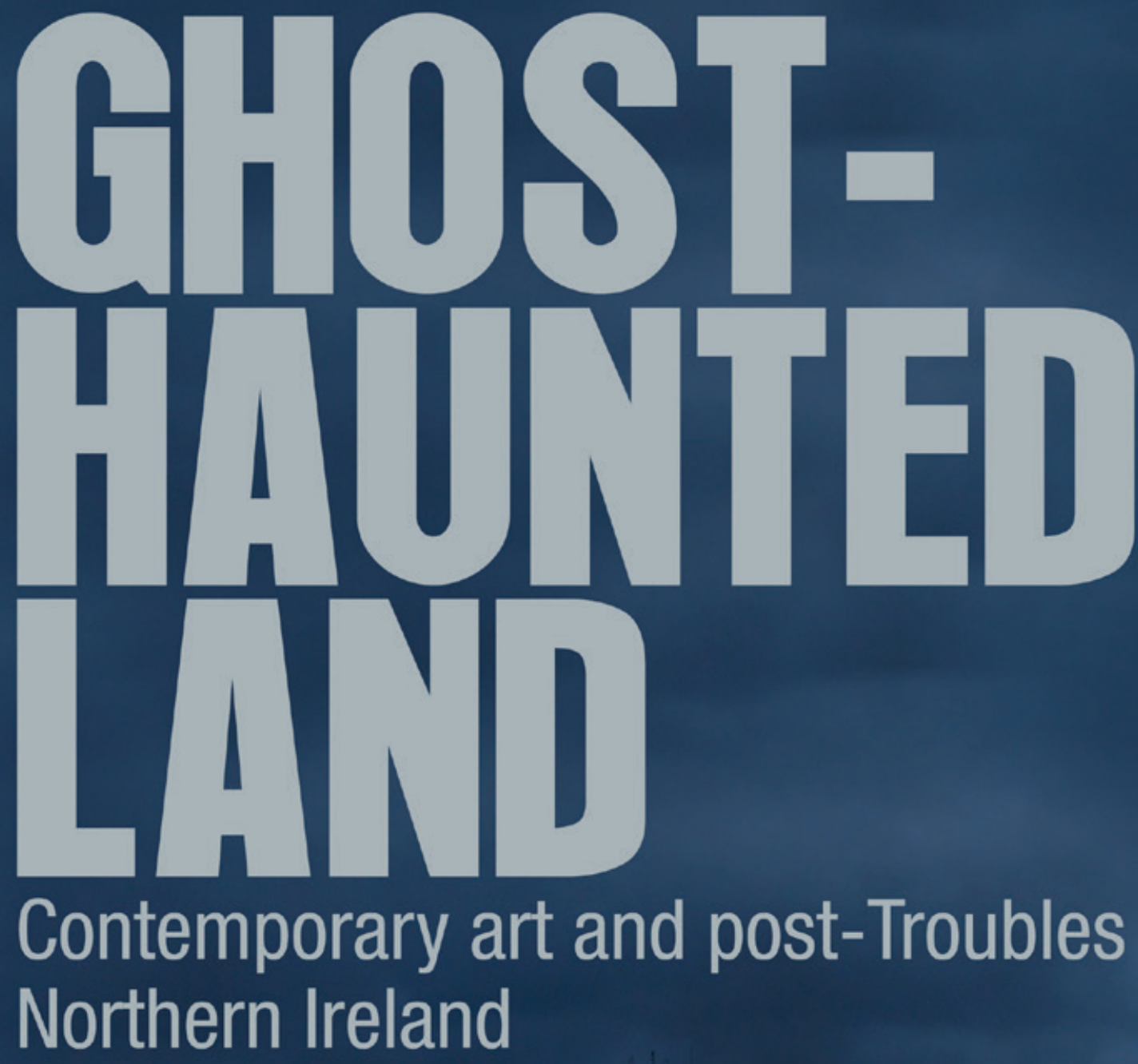

$$
\text { DECLAN }
$$


Declan Long - 9781526121851

Downloaded from manchesterhive.com at $04 / 26 / 2023$ 03:20:50PM 


\section{Ghost-haunted land}

\section{MANCHESTER

Manchester University Press 
Declan Long - 9781526121851

Downloaded from manchesterhive.com at $04 / 26 / 2023$ 03:20:50PM 


\section{Ghost-haunted land}

\section{Contemporary art and post-Troubles Northern Ireland}

\section{Declan Long}

Manchester University Press 
The right of Declan Long to be identified as the author of this work has been asserted by him in accordance with the Copyright, Designs and Patents Act 1988.

Published by Manchester University Press

Altrincham Street, Manchester Mi 7JA

www.manchesteruniversitypress.co.uk

British Library Cataloguing-in-Publication Data

A catalogue record for this book is available from the British Library

ISBN 978 I 784991449 hardback

First published 2017

The publisher has no responsibility for the persistence or accuracy of URLs for any external or third-party internet websites referred to in this book, and does not guarantee that any content on such websites is, or will remain, accurate or appropriate.

Typeset by Out of House Publishing 